\title{
JENIS HIJAUAN PAKAN DAN KECUKUPAN NUTRIEN KAMBING JAWARANDU DI KABUPATEN BREBES JAWA TENGAH
}

\author{
Endang Purbowati, Ikha Rahmawati, dan Edy Rianto \\ FakultasPeternakandanPertanian, UniversitasDiponegoro, Semarang \\ e-mail: purbowati@hotmail.com
}

\begin{abstract}
ABSTRAK
Suatu penelitian survei telah dilaksanakan dengan tujuan untuk mengetahui jenis hijauan pakan dan kecukupan nutrien kambing Jawarandu di Kabupaten Brebes, Provinsi Jawa Tengah. Penelitian ini dilaksanakan di tiga kecamatan, yaitu Kecamatan Tonjong, Bumiayu, dan Paguyangan, melibatkan 504 ekor kambing Jawarandu milik 45 orang peternak. Penentuan lokasi, peternak, dan sampel ternak dilakukan dengan metode purposive sampling. Hasil penelitian menunjukkan bahwa jenis pakan kambing Jawarandu di Kabupaten Brebes adalah Albasia (Albazia falcataria), Mahoni (Swietenia mahagoni), Suren (Toona sureni), Kaliandra (Calliandra haematocephala), dan Gamal (Glyricidia sepium). Nutrien yang dikonsumsi kambing Jawarandu di Kabupaten Brebes melebihi kebutuhan menurut Kearl (1982). Disarankan agar masyarakat peternak kambing Jawarandu di Kabupaten Brebes diberikan penyuluhan/pelatihan tentang manajemen pemberian pakan sehingga pemanfaatan pakan lebih efisien.
\end{abstract}

Kata kunci: hijauan pakan, kambing Jawarandu, kecukupan nutrien.

\begin{abstract}
A survey study was carried out to investigate the kinds of forage and nutrient adequacy of Jawarandu goats in Brebes Regency, Central Java Province. The study was conducted in three sub-districts Tonjong, Bumiayu, and Paguyangan, involving 504 Jawarandu goats belonging to 45 farmers. Determination of the location, farmers and goat as samples was done by purposive sampling method. The results showed that feedstuffs of Jawarandu goat in Brebes Regency were Albasia (Albaziafalcataria), Mahogany (Swietenia mahogany), Suren (Toonasureni), Kaliandra (Calliandrahaematocephala), and Gamal (Glyricidiasepium). Nutrients consumed by Jawarandu goat in BrebesRgency exceeded the needs as recommended by Kearl (1982). It suggested that Jawarandu goat farmers in Brebes Regency be given counseling/training on feeding management for feed utilization being more efficient.
\end{abstract}

Key words: forage, Jawarandu goat, nutrient adequacy

\section{PENDAHULUAN}

Kambing Jawarandu merupakan salah satu primadona ternak yang dipelihara oleh masyarakat di kabupaten Brebes. Kambing Jawarandu dipilih untuk dibudidayakan, karena jenis pakan yang ada di daerah tersebut cocok dan mendukung untuk pemeliharaan kambing, kambing Jawarandu dapat berproduksi sepanjang tahun dan beranak lebih dari satu, serta untuk memenuhi permintaan pasar. Kambing Jawarandu merupakan hasil persilangan antara kambing Kacang dengan kambing Peranakan Etawah sehingga genotip kambing Etawahnya relatif rendah dan genotip kambing Kacangnya relatif tinggi (lebih dari 50\%). Adriani (2003) menyatakan bahwa kambing Jawarandu merupakan kambing tipe dwiguna, yaitu sebagai ternak potong dan ternak perah. Namun kenyataannya di lapangan, kambing Jawarandu lebih banyak ditujukan untuk memproduksi daging (ternak potong).

Kambing Jawarandu yang dibudidayakan di
Kabupaten Brebes memiliki beberapa karakteristik, yaitu memiliki profil muka agak cembung dan telinga menggantung, warna bervariasi antara warna belang coklat putih, belang hitam putih, putih totol hitam atau coklat, coklat, putih, maupun hitam, memiliki tanduk pada kambing jantan maupun betina. Kambing Jawarandu jantan memiliki bulu yang lebat pada paha belakang dan bobot badan dewasanya berkisar antara 21-40 kg (Tidariyanti, 2013), sedangkan pada kambing betina bobot badan dewasanya berkisar antara 18-45 kg (Dewi, 2013).

Pakan merupakan faktor penting dalam mendukung produktivitas ternak. Pemberian pakan yang mencukupi nutrien yang dibutuhkan oleh ternak diharapkan dapat menghasilkan produktivitas ternak yang tinggi. Umumnya, peternakan kambing di Indonesia diusahakan oleh masyarakat sebagai pekerjaan sambilan dan sistem pemeliharaannya masih tradisional, pakan yang diberikan seadanya, sehingga produktivitas yang tinggi sulit dicapai. Penelitian ini bertujuan untuk mengetahui jenis hijauan pakan dan 
kecukupan nutrien kambing Jawarandu di Kabupaten Brebes.

\section{MATERI DAN METODE}

Penelitian dilaksanakan di tiga kecamatan yaitu Kecamatan Tonjong, Bumiayu, dan Paguyangan, Kabupaten Brebes. Penentuan lokasi tersebut dengan metode purposive sampling (Singarimbun dan Effendi, 1995) berdasarkan spesifikasi perkembangan atau kepadatan populasi kambing Jawarandu (Data Laporan Tahunan Dinas Peternakan Kabupaten Brebes).

\section{Materi Penelitian}

Materi yang diamati dalam penelitian ini adalah ternak kambing Jawarandu sebanyak 504 ekor yang terdiri dari 200 ekor jantan muda ( $<6$ bulan), 90 ekor jantan dewasa ( $>6$ bulan), 96 ekor betina muda ( $<6$ bulan), dan betina dewasa ( $>6$ bulan) sebanyak 118 ekor, milik 45 orang peternak dari tiga kecamatan tersebut. Pengambilan peternak sebagai responden dilakukan secara purpossive berdasarkan jumlah kepemilikan kambing (minimal sebanyak 5 ekor) dan pengalaman pemeliharaan kambing (minimal selama 3 tahun). Peralatan yang digunakan antara lain timbangan dalam skala 0,01 kg merk "Hangging Scale" dengan kapasitas $50 \mathrm{~kg}$ untuk menimbang ternak, timbangan merk "Five Goats" dengan kapasitas $3 \mathrm{~kg}$ dan ketelitian $10 \mathrm{~g}$ untuk menimbang pakan. Selain itu juga digunakan daftar pertanyaan sebagai pedoman pada saat pengambilan data penelitian.

\section{Metode Penelitian}

Metode penelitian yang digunakan adalah survey. Pengambilan data dari beberapa peternak dilakukan dengan cara pengamatan, wawancara, pengukuran dan mencatat hal-hal yang diperlukan untuk dianalisis. Selain itu juga dilakukan pengambilan sampel pakan kambing untuk dianalisis kandungan nutrisinya.

\section{Parameter dan Analisis Data Penelitian}

Data yang diambil adalah manajemen pemberian pakan, meliputi jenis pakan, kandungan nutrisi pakan, konsumsi pakan, serta bobot badan dan pertambahan bobot badan ternak untuk evaluasi kecukupan nutrien pakan. Cara pengukuran parameter yang diamati adalah sebagai berikut:

1. Konsumsi pakan didapat dengan menimbang pakan yang diberikan dan sisa pakan keesokan harinya dari setiap bahan pakan yang diberikan. Perhitungan konsumsi pakan segar dapat dilakukan dengan menghitung selisih dari pakan yang diberikan dengan sisa pakan keesokan harinya untuk kambing di kandang individu. Kambing yang di kandang kelompok, pemberian pakan antara induk, jantan, serta anak dicampur menjadi satu, sehingga untuk menghitung konsumsinya menggunakan proporsi berdasarkan bobot badan kambing tersebut. Perhitungan konsumsi pakan dalam bahan kering
(BK), protein kasar (PK), dan total digestible nutrients (TDN) menggunakan rumus:

Konsumsi BK pakan (kg/hari)= BK Pakan (\%) $\mathrm{x}$ konsumsi segar $(\mathrm{kg} / \mathrm{hari})$

Konsumsi PK pakan (kg/hari)= Konsumsi BK pakan (kg/hari) x PK pakan (\%)

Konsumsi TDN pakan (kg/hari)= Konsumsi BK pakan (kg/hari) x TDN pakan (\%)

2. Pertambahan bobot badan harian $(\mathrm{PBBH})$ diperoleh dengan melakukan penimbangan kambing Jawarandu dari umur o hingga 4 tahun untuk mengetahui bobot badannya. Umur ternak diperoleh dari wawancara dengan peternak dan mengamati susunan gigi serinya. Data yang diperoleh digunakan untuk menduga $\mathrm{PBBH}$ kambing Jawarandu yaitu dengan menghitung selisih bobot badan kambing pada umur yang berbeda dibagi jarak waktu dari umur ternak tersebut.

3. Evaluasi kecukupan nutrien dilakukan dengan membandingkan konsumsi pakan kambing Jawarandu dengan kebutuhan pakan menurut Kearl (1982).

Data hasil penelitian dianalisis dengan statistik dan deskriptif dengan membandingkan antara kejadian di lapangan dengan pustaka yang ada.

\section{HASIL DAN PEMBAHASAN}

\section{Keadaan Umum Lokasi Penelitian}

Kabubaten Brebes membentang dari Utara hingga ke Selatan pulau Jawa, sehingga mempunyai semua agroekosistem pedesaan mulai dari pantai hingga dataran tinggi dan hampir sebagian besar masyarakatnya bergerak di bidang pertanian (Prasetyo et al., 2005). Hal ini dapat mendukung perkembangan usaha budidaya peternakan di kabupeten tersebut. Letak Geografis Kabupaten Brebes, antara $108^{\circ} 41^{\prime} 37,7^{\prime \prime}-109^{\circ} 11^{\prime} 28,92$ ' Bujur Timur (BT) dan $6^{\circ} 44^{\prime} 56,5^{\prime \prime}-7^{\circ} 20^{\prime} 51,48^{\prime \prime}$ Lintang Selatan (LS) dan memiliki luas $1.657,72 \mathrm{~km}^{2}$. Kabupeten Brebes memiliki temperatur antara $26-32^{\circ} \mathrm{C}$ dan kelembaban rata-rata sebesar 60-94\%. Batas-batas wilayah Kabupaten Brebes adalah sebagai berikut: Utara dengan Laut Jawa, Selatan dengan Kabupaten Cilacap dan Kabupeten Banyumas, Barat dengan Kabupaten Cirebon dan Kabupaten Kuningan, dan Timur dengan Kabupaten Tegal.

Kabupaten Brebes terdiri dari 17 kecamatan yang terbentang dari daerah pantai hingga pegunungan. Pada penelitian ini, hanya tiga kecamatan yang digunakan untuk pengambilan data, yaitu Kecamatan Tonjong, Paguyangan, dan Bumiayu yang mempunyai tingkat kepadatan kambing yang tinggi di wilayah kabupeten Brebes. Ketiga kecamatan tersebut berada di daerah pegunungan yang terletak di bagian Selatan Brebes, sehingga mendukung ketersediaan pakan hijauan.

\section{Keadaan Umum Peternak}

Umur peternak di Kabupeten Brebes sebagian besar merupakan kelompok umur produktif, yaitu 15-64 
tahun (95,7\%), dan sisanya lebih dari 64 tahun. Umur peternak sangat berpengaruh pada kinerja dan semangat kerja dalam upaya meningkatkan kualitas produk peternakannya. Kelompok umur produktif masih mempunyai kemampuan tenaga dan pikiran untuk menunjang perkembangan usahanya. Abdullah et al. (2012) menyatakan bahwa faktor umur biasanya dikaitkan dengan tingkat produktivitas kerja, apabila seseorang masih tergolong pada usia produktif (2045 tahun) umumnya rasa keingintahuan dan daya adopsinya terhadap teknologi semakin tinggi.

Tingkat pendidikan peternak di Kabupaten Brebes tidak tamat Sekolah Dasar (SD) 6,93\%, tamat SD 88,29\%, dan tamat Sekolah Menengah Pertama (SMP) sebanyak 4,78\%. Tingkat pendidikan peternak berperan dalam mendukung tingkat penerimaan terhadap informasi baru tentang cara pemeliharaan yang baik maupun teknologi baru, sehingga semakin tinggi tingkat pendidikan, maka semakin mudah peternak untuk menyerap informasi baru. Menurut Abdullah et al. (2012), semakin tinggi tingkat pendidikan peternak, maka semakin tinggi kualitas sumber daya manusia, seperti meningkatnya pengetahuan dan keterampilan, sehingga meningkatkan produktivitas kerja dan keberhasilan usaha ternak.

Mata pencaharian peternak hampir seluruhnya sebagai petani, yaitu 95,7\%, dan hanya 4,3\% yang bukan petani. Jenis mata pencaharian peternak berperan dalam mendukung tingkat keberhasilan usaha peternakan kambing Jawarandu terutama dalam hal manajemen pemeliharaan ternak. Pekerjaan di bidang pertanian sangat mendukung usaha beternak kambing, karena terdapat sistem timbal balik antara pertanian dan peternakan, yaitu lahan pertanian dapat menyediakan pakan untuk ternak serta limbah ternak yang berupa feses dan sisa pakan dapat dimanfaatkan sebagai pupuk organik untuk lahan pertanian. Abdullah et al. (2012) menyatakan bahwa sistem usaha pertanian dan peternakan yang dilakukan secara bersamaan dapat membawa dampak budidaya, sosial, dan ekonomi yang positif, yaitu usaha ternak semakin efisien dengan ketersediaan pakan yang dapat dilakukan secara kontinyu dan berkelanjutan yang dapat berasal dari lahan pertanian, sedangkan usaha pertanian juga mendapatkan keuntungan dengan memanfaatkan limbah peternakan untuk pupuk.

Data pengalaman beternak sebagian besar berkisar selama $3-10$ tahun $(66,91 \%)$, kemudian 11-20 tahun (19,71\%), 21-30 tahun (10,15\%), dan > 30 tahun (3,23\%). Pengalaman beternak dapat mempengaruhi kerangka berpikir dalam menentukan perencanaan, pemeliharaan, dan pasca produksi berdasarkan pengalaman yang telah dikuasainya. Pada peternakan rakyat, sebagian besar para peternak belajar otodidak atau belajar sendiri dari orang tuanya maupun pengalaman sendiri. Hal ini sesuai dengan pendapat Abdullah et al. (2012), bahwa dengan pengalaman beternak yang cukup lama mengindikasikan pengalaman dan keterampilan peternak terhadap manajemen pemeliharaan ternak mempunyai kemampuan yang semakin baik.

\section{Jenis Hijauan Pakan}

Manajemen pemeliharaan kambing Jawarandu di Kabupaten Brebes secara intensif (dikandangkan), sehingga pakan disediakan oleh peternak. Manajemen pemberian pakan kambing Jawarandu di Kabupaten Brebes sebagian besar termasuk kriteria kurang (50\%). Aspek pemberian pakan yang belum diperhatikan oleh para peternak, yaitu pada aspek jumlah pemberian dan pengolahan/pengawetan pakan. Jenis bahan pakan yang diberikan kepada ternak semuanya berupa tanaman legum pohon maupun pohon lainnya atau sering disebut rambanan, seperti Albasia (Albazia falcataria), Mahoni (Swietenia mahagoni), Suren (Toona sureni), Kaliandra (Calliandra haematocephala), maupun Gamal (Glyricidia sepium). Pemberian pakan tambahan, seperti konsentrat belum dilakukan oleh peternak, karena pengetahuan tentang pakan tambahan belum dimengerti oleh sebagian besar peternak. Namun untuk memenuhi kebutuhan protein, telah terpenuhi dari pemberian pakan berupa tanaman legum pohon tersebut. Hal ini tidak sesuai dengan pendapat Rianto dan Purbowati (2009) bahwa pemeliharaan secara intensif, pakan hijauan dan konsentrat diberikan kepada ternak di dalam kandang, sehingga kecukupan nutrisi ternak dapat terpenuhi.

Hasil analisis kandungan nutrisi bahan pakan yang diberikan kepada kambing di Kabupaten Brebes dapat dilihat pada Tabel 1. Kandungan protein kasar bahan pakan yang diberikan pada kambing Jawarandu cukup tinggi, kecuali mahoni yang hanya 12,09\%. Kandungan serat kasar kaliandra, gamal, dan albasia cukup rendah (kurang dari 18\%), sedangkan mahoni dan suren mempunyai kandungan serat kasar lebih dari $18 \%$.

Tabel 1. Kandungan Nutrisi Bahan Pakan yang Diberikan kepada Ternak Kambing Jawarandu di Kabupaten Brebes

\begin{tabular}{|c|c|c|c|c|c|c|c|}
\hline \multirow{3}{*}{$\begin{array}{l}\text { Bahan } \\
\text { Pakan }\end{array}$} & \multirow[b]{2}{*}{ BK } & \multicolumn{5}{|c|}{ Kandungan Nutrisi (100\% bahan kering) } & \multirow[b]{2}{*}{ TDN } \\
\hline & & Abu & $\begin{array}{c}\text { Lemak } \\
\text { Kasar }\end{array}$ & $\begin{array}{c}\text { Protein } \\
\text { Kasar }\end{array}$ & $\begin{array}{l}\text { Serat } \\
\text { Kasar }\end{array}$ & BETN & \\
\hline & \multicolumn{7}{|c|}{--------------------------------------------- (\%) ------------------------------ } \\
\hline Kaliandra & 80,29 & 5,55 & 1,73 & 30,22 & 9,99 & 52,51 & 78,10 \\
\hline Mahoni & 82,85 & 7,47 & 1,55 & 12,09 & 27,98 & 50,91 & 61,70 \\
\hline Suren & 75,48 & 11,35 & 1,88 & 32,52 & 21,06 & 33,19 & 64,57 \\
\hline Gamal & 72,73 & 18,92 & 3,38 & 30,04 & 12,70 & 34,96 & 64,79 \\
\hline Albasia & 70,93 & 8,14 & 2,47 & 27,34 & 14,54 & 47,51 & 72,16 \\
\hline
\end{tabular}

Keterangan: $\mathrm{BETN}=$ bahan ekstrak tanpa nitrogen; TDN dihitung menurut persamaan Harris et al. dalam Hartadi et al. (2005).

\section{Konsumsi Pakan}

Hasil perhitungan konsumsi dan kebutuhan pakan kambing Jawarandu di Kabupaten Brebes dapat dilihat pada Tabel 2. Kambing Jawarandu betina pada umur muda ( $\leq 6$ bulan) mengkonsumsi BK, PK, dan TDN lebih rendah dari pada jantan muda, namun kambing Jawarandu betina dewasa ( $>6$ bulan) mampu mengkonsumsi BK, PK, dan TDN yang lebih tinggi dari pada jantan dewasa. Hal ini dikarenakan bobot badan kambing yang berbeda yaitu pada jantan muda $11,84 \mathrm{~kg}$, jantan dewasa 29,80 kg, betina muda $10,13 \mathrm{~kg}$, dan betina dewasa $31,18 \mathrm{~kg}$. Bobot badan kambing jantan muda lebih tinggi dari pada betina 
muda, karena ternak jantan umumnya mempunyai bobot lahir yang lebih tinggi dan laju pertumbuhan yang lebih cepat. Bobot badan kambing jantan dewasa hasil penelitian ini lebih rendah dari pada betina dewasa, karena umur ternak jantan dewasa yang dapat diketemukan di lapangan hanya sampai poel 2 (kirakira berumur $2-3$ tahun), sedangkan pada betina dewasa sampai poel 4 (kira-kira berumur 4 - 5 tahun).

Hasil perhitungan persentase konsumsi BK dari bobot badan kambing Jawarandu di kabupaten Brebes adalah 4,53\% (jantan muda), 3,58\% (jantan dewasa), 3,99\% (betina muda), dan 3,95\% (betina dewasa). Persentase konsumsi BK kambing Jawarandu di Brebes sedikit lebih tinggi dari pendapat Kearl (1982) yaitu $2,9-3,8 \%$ dari bobot badan. Hal ini menunjukkan bahwa kemampuan konsumsi BK kambing Jawarandu di Brebes cukup tinggi.

\section{Pertambahan Bobot Badan Harian}

Pertambahan bobot badan harian $(\mathrm{PBBH})$ kambing Jawarandu jantan pada umur muda ( $\leq 6$ bulan) sebesar 71,20 g dan pada umur dewasa ( $>6$ bulan) sebesar 42,30 g. Sementara itu PBBH kambing Jawarandu betina muda ( $\leq 6$ bulan) sebesar 69,20 g dan pada umur dewasa ( $>6$ bulan) sebesar 39,60 g. Pertambahan bobot badan harian ternak jantan lebih tinggi daripada betina pada setiap kelompok umur. Hal ini diakibatkan oleh perbedaan sistem hormonal yang mengatur pertumbuhan pada ternak jantan dan betina. Menurut pendapat Rianto dan Purbowati (2009), perbedaan PBBH ternak jantan dan betina disebabkan oleh perbedaan sistem hormonal pada ternak yang memacu pertumbuhan, sehingga ternak jantan akan lebih cepat tumbuh atau mempunyai pertambahan bobot badan yang lebih tinggi dibandingkan ternak betina.

Hasil penelitian menunjukkan, bahwa kambing Jawarandu muda mempunyai PBBH yang lebih tinggi dari pada kambing Jawarandu dewasa, baik pada umur muda maupun dewasa. Hal ini karena kambing muda masih berada pada fase kecepatan pertumbuhan dipercepat, sedangkan kambing dewasa sudah berada pada fase kecepatan pertumbuhan diperlambat. Saat berada di fase kecepatan pertumbuhan dipercepat, kadar growth hormon tinggi. Kambing Jawarandu jantan muda mempunyai PBBH yang lebih tinggi dari pada betina muda, selain karena faktor hormonal juga disebabkan konsumsi BK, PK, dan TDN yang lebih tinggi pada kambing jantan (Tabel 2), sebagaimana dinyatakan oleh Syuhada et al. (2009), Munier (2005), dan Martawidjaja et al. (1999), bahwa perbedaan $\mathrm{PBBH}$ pada setiap individu ternak dapat diakibatkan oleh faktor pakan. Kambing Jawarandu betina dewasa mempunyai $\mathrm{PBBH}$ yang lebih rendah dari pada jantan dewasa meskipun konsumsi pakannya lebih tinggi, disamping disebabkan oleh sistem hormonal yang berbeda, juga karena pakan yang dikonsumsi kambing betina dewasa tidak hanya digunakan untuk $\mathrm{PBBH}$, tetapi juga untuk produksi anak (bunting dan menyusui).
Tabel 2. Konsumsi dan Kebutuhan Pakan Kambing Jawarandu di Kabupaten Brebes

\begin{tabular}{|c|c|c|c|c|c|c|}
\hline \multirow{3}{*}{ Kambing } & \multicolumn{2}{|c|}{ Bahan Kering } & \multicolumn{2}{|c|}{ Protein Kasar } & \multicolumn{2}{|c|}{$\begin{array}{c}\text { Total Digestible } \\
\text { Nutrients }\end{array}$} \\
\hline & Konsumsi & $\begin{array}{l}\text { Kebutu- } \\
\text { han }\end{array}$ & Konsumsi & $\begin{array}{l}\text { Kebutu- } \\
\text { han }\end{array}$ & Konsumsi & $\begin{array}{l}\text { Kebutu- } \\
\text { han }\end{array}$ \\
\hline & \multicolumn{6}{|c|}{ - } \\
\hline \multicolumn{7}{|l|}{ Jantan } \\
\hline a. Muda ${ }^{2)}$ & 536 & 410 & 144 & 47 & 383 & 308 \\
\hline b. Dewasa ${ }^{3)}$ & 1.067 & 787 & 286 & 68 & 762 & 443 \\
\hline \multicolumn{7}{|l|}{ Betina } \\
\hline a. Muda2) & 404 & 358 & 108 & 44 & 288 & 290 \\
\hline b. Dewasa ${ }^{3)}$ & 1.233 & 808 & 330 & 69 & 880 & 450 \\
\hline
\end{tabular}

1) Kebutuhan menurut Kearl (1982)

2) Umur $<6$ bulan

3) Umur $>6$ bulan

\section{Kecukupan Nutrien}

Berdasarkan bobot badan dan pertambahan bobot badan yang dihasilkan, dapat dihitung kebutuhan pakan kambing menurut rekomendasi Kearl (1982) yang disajikan pada Tabel 2. Hasil perhitungan konsumsi pakan kambing Jawarandu di Kabupaten Brebes dan kebutuhan pakan menurut Kearl (1982), menunjukkan bahwa hampir semua konsumsi nutrien (BK, PK, dan TDN) mencukupi kebutuhan (bahkan berlebih), kecuali konsumsi TDN pada kambing betina muda kurang $2 \mathrm{~g}$.

Apabila dilihat dari dari selisih antara konsumsi dan kebutuhan pakan (Tabel 2), maka untuk mendapatkan PBBH yang sama, kambing di kabupaten Brebes membutuhkan pakan yang lebih banyak, sehingga pemanfaatan pakan kambing kurang efisien. Hal ini kemungkinan dikarenakan kebutuhan pakan untuk hidup pokok dan produksi kambing di Brebes lebih besar. Selain itu, kemungkinan karena jenis pakan berupa tanaman leguminosa pohon sehingga kecernaannya lebih rendah. Purbowati (2007) melaporkan bahwa pakan domba di pedesaan umumnya berupa rumput dan leguminosa pohon mempunyai kadar neutral detergent fiber (NDF) dan acid detergent fiber (ADF) yang relatif tinggi, yaitu NDF 56,79\% dari bahan kering, dan ADF 68,30\% dari $\mathrm{NDF}$, sehingga diduga bahwa tingkat kecernaan pakan tersebut rendah. Pakan dengan kandungan ADF tinggi pada umumnya juga mengandung lignin yang tinggi pula, yang menyebabkan kecernaan pakan rendah (McDonald et al., 1988).

\section{SIMPULAN}

Simpulan hasil penelitian ini adalah jenis pakan kambing Jawarandu di Kabupaten Brebes adalah Albasia (Albazia falcataria), Mahoni (Swietenia mahagoni), Suren (Toona sureni), Kaliandra (Calliandra haematocephala), dan Gamal (Glyricidia sepium). Nutrien yang dikonsumsi kambing Jawarandu di Kabupaten Brebes melebihi kebutuhan menurut Kearl (1982), sehingga pemanfaatan pakan kurang efisien. Saran yang dapat diberikan adalah masyarakat peternak kambing Jawarandu di Kabupaten Brebes perlu diberikan penyuluhan/pelatihan tentang 
manajemen pemberian pakan sehingga pemanfaatan pakan lebih efisien.

\section{UCAPAN TERIMA KASIH}

Ucapan terima kasih disampaikan kepada Kepala dan staf Dinas Peternakan Kabupaten Brebes serta warga masyarakat di KecamatanTonjong, Paguyangan, dan Bumiayu yang telah memberi kesempatan dan membantu pelaksanaan penelitian serta pengambilan data, keluarga besar Bapak Agus Tofan selaku petugas teknis lapangan Dinas Peternakan Kabupaten Brebes atas bantuan dan rasa kekeluargaannya. Asma Armelia Dewi dan Garnis Tidariyanti terima kasih atas kerjasamanya selama penelitian.

\section{DAFTAR PUSTAKA}

Abdullah, A., M. Aminawar, A. H. Hoddi, H. M. Ali, dan J. A. Syamsu. 2012. Identifikasi kapasitas peternakan dalam adopsi teknologi untuk pengembangan sapi potong yang terintegrasi dengan padi. Dalam: E.T. Marlina, E. Abustaman, A. Yaman, L. Nurlina, S. Rahayu, H. Setiyatwan, D.S. Tasripin, E. Nurdin, T. Wijastuti, L. Suryaningsih, D. Rusmana, H. Arief, dan Dudi (Eds). Prosiding Seminar Nasional Peternakan Berkelanjutan IV "Inovasi Agribisnis Peternakan untuk Ketahanan Pangan”. Jatinangor, 7 November 2012. Fakultas Peternakan, Universitas Padjadjaran. Bandung. Hal: 304-308

Adriani, A. Sudono, T. Sutardi, W. Manalu, dan I .K. Sutama. 2003. Optimasi produksi anak dan susu kambing peranakan etawah dengan superovulasi dan suplementasi seng. Forum Pascasarjana. Sekolah Pascasarjana, Institut Pertanian Bogor 26 (4): 335-352.

Dewi, A.A. 2013. Hubungan Ukuran-ukuran Tubuh dengan Bobot Badan Kambing Jawarandu Betina Umur 0-4 Tahun di Kabupaten Brebes. Skripsi. Fakultas Peternakan dan Pertanian, Universitas Diponegoro, Semarang.

Hartadi, H., S. Reksohadiprodjo dan A. D. Tillman. 2005. Tabel Komposisi Pakan untuk Indonesia. Gadjah Mada University Press, Yogyakarta.
Kearl, L. C. 1982. Nutrient Requirements of Ruminants in Developing Countries. International Feedstuffs Institute Utah Agricultural Experiment Station Utah State University, Logan Utah.

Martawidjaja, M., B. Setiadi dan S. S. Sitorus. 1999. Pengaruh Tingkat Protein-Energi Ransum Terhadap Kinerja Produksi Kambing Kacang Muda. J. Ilmu Ternak dan Veteriner. 4 (3): 167-173.

McDonald, P., Edwards, R.A. and Greenhalgh, J.F.D. (1988). Animal Nutrition, $4^{\text {th }}$ Ed. Longman Scientific and Technical, Harlow.

Munier F. F. 2005. Bobot Hidup Domba Ekor Gemuk (DEG) yang Diberikan Pakan Tambahan Leguminosa. Dalam: I. W. Mathius, S. Bahri, Tarmudji. L. H. Prasetyo, E. Triwulanningsih, B. Tiesnamurti, I. Sendow dan Suharono. Prossiding Seminar Nasional Teknologi Peternakan dan Veteriner. Bogor 12-13 September 2005. Pusat Penelitian dan PengembanganPeternakan. Hal: 410-415.

Prasetyo. A., Muryanto, T. Herawati, dan Samijan. 2005. Peta Daya Dukung Wilayah untuk Pengembangan Ternak Ruminansia di Kabupaten Brebes. Dalam: I. W. Mathius, S. Bahri, Tarmudji. L. H. Prasetyo, E. Triwulanningsih, B. Tiesnamurti, I. Sendow dan Suharono. Prossiding Seminar Nasional Teknologi Peternakan dan Veteriner. Bogor 12-13 September 2005. Pusat Penelitian dan Pengembangan Peternakan. Hal: 559-572.

Purbowati, E. 2007. Kajian Perlemakan Karkas Domba Lokal dengan Pakan Komplit dari Jerami Padi dan Konsentrat pada Bobot Potong yang Berbeda. Disertasi.Univesitas Gadjah Mada, Yogyakarta.

Rianto, E. dan E. Purbowati. 2009. Panduan Lengkap Sapi Potong. Penebar Swadaya, Jakarta.

Singarimbun, M. dan S. Effendi. 1995. Metode Penelitian Survai. PT Pustaka LP3ES, Jakarta.

Syuhada, T. R., E. Rianto, E. Purbowati, A. Purnomoadi, dan Soeparno. 2009. Produktivitas Sapi Peranakan Ongole Jantan pada Berbagai Tingkat Bobot Badan. Dalam: Y. Sani, L. Natalia, B. Brahmantiyo, W. Puatuti, T. Sartika, Nurhayati, A. Anggraeni, P. H. Matondang, E. Martindah, dan S. E. Estuningsih (Eds). Prosiding Seminar Nasional Teknologi Peternakan dan Veteriner. Bogor 13-14 Agustus 2009. Pusat Penelitian dan Pengembangan Peternakan. Hal: 163-172.

Tidariyanti, G. 2013. Hubungan Ukuran-ukuran Tubuh dengan Bobot Badan Kambing Jawarandu Jantan di Kabupaten Brebes. Skripsi. Fakultas Peternakan dan Pertanian, Universitas Diponegoro, Semarang. 